\title{
Automated Microsprinkler to Determine the Crop Coefficient in Tomato Seedling Cultivated with Hydroretentor
}

\author{
Catariny Cabral Aleman and Flávio Campos Bastos \\ Agricultural Engineering Departament, Federal University of Viçosa, Ph Rolfs Avenue, s/n, Campus Universitário, Viçosa-MG \\ 36572-028, Brazil
}

\begin{abstract}
The objective of this study was to obtain the weekly crop coefficient $(K c)$ for tomato seedlings in substratum with waterproofing polymer and irrigated by automatic system of localized irrigation. The experiment was conducted in an agricultural greenhouse located in the irrigation experimental area of the Department of Agricultural Engineering, Viçosa-MG, Brazil. The crop coefficient $(K c)$ for tomato seedlings was obtained for the conditions of the experiment (in plastic trays of 128 cells, in greenhouse, in Viçosa-MG, for the spring/summer season), using the substrates with and without hydrogel. The irrigation system was micro sprinkler, consisting of four emitters per tray of seedlings, so that each tray constitutes an individualized experimental unit. The method for estimation of reference evapotranspiration was Penman-Monteith FAO56. The weighing lysimetry was used to obtain the variation of the tray mass from the evapotranspiration of the culture. Two consecutive daily weights, spaced at intervals of 60 min (during the morning shift), were performed for five sample units (SU) arranged in a completely randomized design in the greenhouse. Each SU was composed of a tray of 128 cells. The values of $K c$ obtained were used to calibrate the crop evapotranspiration (ETC) estimates used in the later stages. Weekly $K c$ values were generated. Irrigation was managed so that the crop did not undergo water stress during the moulting phase. For the conditions tested it was possible to obtain Kc values between 0.72 and 2.86 for the substrate without hydrogel and 0.81 to 3.46 for the substrate with hydrogel. It should be considered that the production stage of seedlings is very demanding in water and in protected environment conditions it is possible to obtain high $K c$ values.
\end{abstract}

Key words: Water need, water economy, automatic irrigation.

\section{Introduction}

Considering the process of producing vegetables as a whole, the production stage of seedlings is one of the most important because good quality seedlings enable plants to express their genetic potential and directly influence productivity $[1,2]$.

Water management in irrigated agriculture doesn't only refer to the control of water in the production system, but involves knowing both the soil or substrate and its physical characteristics, as well as knowing the climatic variables that are directly related to crop production, such as air temperature, relative humidity of the air and incident solar radiation, thus

Corresponding author: Catariny Cabral Aleman, professor, research fields: irrigation management, economic viability of irrigation, irrigated agriculture. estimating evapotranspiration rates in the production environment. Water management also involves knowing the behavior of the irrigation system used. In this way one can determine the most appropriate moment, in which form and the amount of water to be supplied to the crop [2].

Often, in practice, production systems don't operate under efficient management, not because of a lack of technology or capital, but because decisions are taken improvised, randomly, carelessly or subjectively by the producer; even if based on field experience, are subject to greater divergence, causing unfavorable environments for the development of seedlings and the emergence of diseases and other stresses [2]

Irrigation management in production systems of vegetable, spice, medicinal and ornamental plants in 
trays and pots is of great difficulty. It is a challenge because the amount of water retained in the substrate, in a restricted volume of substrate, that is available to the roots is small, requiring several daily irrigations [3]. In addition, each irrigation event requires a small blade applied so that there is no percolation and "washing" of nutrients, nor does it flow through the vessels and trays.

The crop evapotranspiration (ETC) can be estimated by several empirical models. It can also be obtained experimentally from the water balance in evaporative tanks, such as the class A tank [4] or in lysimeters. These are structures (experimental assemblies) capable of measuring small variations in mass (lysimeter of weighing) or in volume (drainage lysimeter or percolation) of a cultured container [5]. These changes in weight or volume are associated with the inflow and outflow of water from the system and through the water balance - knowing the irrigated, precipitated and drained the depth - it is possible to obtained the quantitative value for ETC [5].

Among the empirical models, the most commonly used is the simple culture coefficient equation, also known as the FAO24 model, which relates ETC to reference evapotranspiration by a single crop coefficient $(K c)$, suggested in the FAO Bulletin 24 and reinforced in the FAO Bulletin 56 [5].

The crop coefficient can affect according of soil characteristics (physical and chemical soil, highlighting the influence of soil water content on $E T C$ ), the plant conditions (development stage, genetic characteristics, nutritional status, phytosanitary conditions) and the climatic conditions of the site (reference evapotranspiration). It's possible to obtain the crop coefficient considering the losses of the crop in the climatic conditions considering the ratio crop evapotranspiration and reference evapotranspiration [5]. Therefore, knowing the Kc values of a crop with good accuracy for specific growing conditions is greatly increasing the chances of establishing good irrigation management.
Water retention capacity (WRC) is an important parameter in irrigation management because it relates the water content retained in the soil/substrate consider the field capacity and the point tension of permanent wilt. The field capacity conditions are important to define the hydric conditions for developing the root system. These data are easily obtained through the retention curve (RC) of the soil/substrate.

The WRC is related, among other factors, to the porosity (macroporosity and microporosity) of the soil. The total porosity is related to the volume of water retained in the saturated samples. Microporosity is related to most of the water retained in the soil matrix (which is adsorbed on the micropores). Soils with a higher proportion of particles of silt and mainly clay are generally soils with higher microporosity, tend to have higher WRC. Soils with higher macroporosity tend to have good drainage, but do not necessarily have high WRC. These soils have a higher proportion of particles in the sand fraction [6].

The agricultural use of hydrophobic polymers (hydrophilic polymer, hydrogels) began to be studied in the 1950s. There are several applications for these products, covered by different technological areas recommend [7] on the characterization and applications of hydrogels.

The use of these soil conditioners has been studied in the last decades for several crops, also in the field, but mainly for the production of seedlings. In this work, the authors present the results of a study of the species of Pinus sylvestris [8]. In Brazil, the soil conditioners are used in Brazilian native trees [9], in canola [10], corn, soybean [11] and coffee [12]. In others crops, the results of the experiment were carried out in the same way as the case of carrots [13] and vegetables such as sweet peppers [14], carrots [15], tomato [16] and lettuce [17].

The objective of the work was to determine the crop coefficient for tomato cultivated in substrate with and without hydrogel irrigated with automatic irrigation 
system.

\section{Materials and Methods}

The experiment was conducted in an agricultural greenhouse located in the experimental field of Diogo Alves de Mello, Viçosa-MG (20 46'04" S, 42 ${ }^{\circ} 52^{\prime} 10^{\prime \prime}$ $\mathrm{W}$, altitude $662 \mathrm{~m}$ ), in the Federal University of Viçosa, Viçosa, Minas Gerais, Brazil. The climate of the region is of the "Cwa" type (classification of Köppen), characterized by the tropical climate of altitude, with rains in the summer and dry in the winter.

The tomato seeds ISLA ${ }^{\circledR} \quad$ (Lycopersicon esculentum Mill.) were used for the production of seedlings. The crop coefficient $(K c)$ for tomato seedlings in the condition of plastic trays, of 128 cells, in a greenhouse, in Viçosa-MG, was obtained for the spring/summer season (considering January until February), in the absence and presence of hydrogel on the substrate.

The irrigation system was micro sprinkler, consisting of four emitters per tray of seedlings, so that each tray constitutes an individualized experimental unit. The system was automated with solenoid valves to drive according to the greenhouse climatic variables.

The method for estimation of reference evapotranspiration was Penman-Monteith FAO56. Weighing lysimetry was used to obtain the variation of the tray mass from the evapotranspiration of the culture. Two consecutive daily weights spaced from $60 \mathrm{~min}$ intervals (during the morning shift), were performed for five sample units (SU) arranged in a completely randomized design in the greenhouse. Each SU was composed of a tray of 128 cells.
Through the trays weight variation it was possible to determine the crop evapotranspiration.

The Kc was calculated with Eq. (1):

$$
\begin{aligned}
& K_{C}=\frac{E T_{C}}{E T_{O}} \\
& E T_{C}=\Delta m=m_{j+1}-m_{j} \\
& E T_{O}=\sum_{K} E T_{O, K}
\end{aligned}
$$

where $K c$ is crop coefficient; ETo is reference evapotranspiration; ETC is crop evapotranspiration; $K$ is $\mathrm{SU}$ numbers observed daily; $\Delta m$ is variation of the water mass and $j$ is weighing index.

The $K c$ values were determined for seedlings grown on commercial substrate for pure vegetables and on substrate containing hydrogel. These values were used to calibrate the ETC estimates used in the later stages.

Weekly $K c$ values were generated. These were compared among themselves in order to obtain a temporal evolution pattern for $K c$ of seedlings. The $K c$ values obtained the substrate with hydrogel and without hydrogel were also compared.

Irrigation was managed so that the crop did not undergo water stress during the moulting phase.

\section{Results and Discussion}

During the trial period temperatures ranged from $17.6^{\circ} \mathrm{C}$ to $28.9^{\circ} \mathrm{C}$ and the ETo was $3.39 \mathrm{~mm} / \mathrm{d}$.

According to the results obtained (Table 1), it was possible to verify the increase in water demand at different growing seasons of tomato plants. The variations observed for both tomatoes grown with substrate without hydrogel and with hydrogel may be caused by the cell size of the polyethylene trays and the growth of the plants causing a "bouquet" effect.

Table 1 Crop coefficient of tomato without hidrogel (TW) and tomato with hydrogel (TH) considering six weeks during January until February.

\begin{tabular}{llllccc}
\hline & \multicolumn{5}{c}{ Weeks } \\
\cline { 2 - 7 } Treatment & 1 & 2 & 3 & 4 & 5 & 6 \\
\cline { 2 - 7 } & 0.72 & 0.87 & 1.23 & 1.47 & 1.79 & 2.86 \\
TW & 0.81 & 0.99 & 1.47 & 1.78 & 2.97 & 3.46 \\
TH & 0.970 coefficient \\
\hline
\end{tabular}


The crop coefficient $(K c)$ is fundamental to the size and management of irrigation of a crop, and since these values vary according to the energy availability of the site, variety and age of the plant, it is important to obtain regionalized values [18]. There are no studies on the determination of the crop coefficient for tomato seedlings.

For tomato seedlings cultured with substrate with hydrogel (T2) an exponential growth occurred tending to the stability in the final period of the seedling phase. Loose et al. [19] found that the $K c$ values correlated with days after transplanting (DAT) and culture cycle. In the spring period a sigmoidal relationship between $K c$ and DAT occurred, with small values of $K c$ being obtained in the first DAT, tending to an almost exponential growth and later stablishing according to the culture demand.

The use of hydrogel increased the value of the culture coefficient for seedlings cultured with substrate plus hydrogel. This may demonstrate that there is a greater water demand for this culture condition over the substrate without hydrogel. Azambuja et al. [20] concluded that for cultivation of zucchini cultivar Caserta the use of hydrogel in the culture substrate did not influence seedlings and fruit production.

There are few studies on the determination of seedling crop coefficient, considering the conditions of seedling cultivation to be different from the field conditions. Thus, there are no tables to verify variations in crop coefficient values for tomato and other vegetables.

In the estimates of evapotranspiration the environment is represented by reference evapotranspiration and $K c$ translates to the effects of the plants on evapotranspiration. The values of $K c>1$ occur because the tray culture system is a very intensive system. There are 128 seedlings in 0.1352 $\mathrm{m}^{2}$. In a few days the seedlings shade the tray and increase the perspiration component, and considering a system of irrigation with leaf wetting, the leaves of the seedlings end up receiving much of the applied water, returning it quickly to the environment by evaporation. This effect associated with the intensity of the trays culture system justifies a high value of $K c$ for seedling phase.

The presence of the hydrogel in the substrate causes an increase in the water retention, improving the efficiency of the hydrogel [18] and nutrients [6], so that the seedlings do not undergo water stress or nutritional and, therefore, grow vegetatively better [21]. The initial vegetative development influences the increase in the length of the aerial part or the leaf area. This phase is important for preparing to the production phase when the plants have higher water consumption [5].

\section{Conclusions}

For the conditions tested it was possible to obtain Kc values between 0.72 and 2.86 for the substrate without hydrogel and 0.81 to 3.46 for the substrate with hydrogel.

In conditions of greenhouse, it's possible to obtain high values of crop coefficient because the seedlings have been a higher demanding of water. In conditions of cultivation in trays the area is smaller and the plants have smaller space between them which can cause the effect of microclimate and increase of the culture coefficient.

\section{References}

[1] Reghin, M. Y., Otto, R. F., Olinik, J. R., and Jacoby, C. F. S. 2007. "Viability of the Seedling Production System in Trays in Three Onion Cultivars." Ciência $e$ Agrotecnologia 31 (4): 1075-84. (in Portuguese)

[2] Gupta, M. K., Samuel, D. V. K., and Sirohi, N. P. S. 2010. "Decision Support System for Greenhouse Seedling Production." Computers and Electronics in Agriculture 73 (2): 133-45.

[3] Chappell, M., Dove, S. K., van Iersel, M. W., Thomas, P. A., and Ruter, J. 2013. "Implementation of Wireless Sensor Networks for Irrigation Control in Three Container Nurseries." HortTecnology 23 (6): 747-53.

[4] Snyder, R. L. 1992. "Equation for Evaporation Pan to Evapotranspiration Conversions." Journal of Irrigation 


\section{Automated Microsprinkler to Determine the Crop Coefficient in Tomato Seedling Cultivated with Hydroretentor}

and Drainage 118 (6): 977-80.

[5] Allen, R. G., Pereira, L. S., Raes, D., and Smith, M. 1998. "Crop Evapotranspiration-Guidelines for Computing Crop Water Requirements." FAO Irrigation and Drainage Paper 56, Food and Agriculture Organization, Rome.

[6] Fagundes, M. C. P., Cruz, M. Do C. M., De Carvalho, R. P., Oliveira, J., and Soares, B. C. 2015. "Hydroabsorbent Polymer in the Reduction of Leached Nutrients during the Production of Yellow Passion Fruit Seedlings." Revista Caatinga 28 (1): 121-9. (in Portuguese)

[7] Ahmed, E. M. 2015. "Hydrogel: Preparation, Characterization and Applications: A Review." Journal of Advanced Research 6 (2): 105-21.

[8] Sarvaš, M., Pavlenda, P., and Takácová, E. 2007. "Effect of Hydrogel Application on Survival and Growth of Pine Seedlings in Reclamations." Journal of Forest Science 53 (5): 204-9.

[9] Barbosa, T. C., Rodrigues, R. R., and Couto, H. T. Z. De. 2013. "Container Sizes and the Use of Hydrogels in Establishing Seedlings of Native Forest Species." Hoehnea 40 (3): 537-56.

[10] Tohidi-Moghadam, H. R., Shirani-Rad, A. H., Nour-Mohammadi, G., Habibi, D., Modarres-Sanavy, S. A. M., Mashhadi-Akbar-Boojar, M., and Dolatabadian, A. "Response of Six Oilseed Rape Genotypes to Water Stress and Hydrogel Application." Pesquisa Agropecuária Tropical 39 (3): 243-50. (in Portuguese)

[11] Gakes, D. C., Trinca, L. C., Catalina, A. C., and Jitareanua, A. P. 2016. "Effects of a Hydrogel on the Cambic Chernozem Soil's Hydrophysic Indicators and Plant Morphophysiological Parameters." Geoderma 267: 102-11.

[12] Marques, P. A. A., Cripa, M. A. De M., and Martinez, E. H. "Hydrogel as a Substitute for Complementary Irrigation in Coffee Seedlings Nursery." Ciência Rural 43 (1): 1-7. (in Portuguese)

[13] Resende, G. M., and Cordeiro, G. G. 2007. "Carrot Productivity in the Function of the Water Quality and Soil Conditioner in São Francisco Valley." Revista
Caatiga 20 (1): 100-4. (in Portuguese)

[14] Marques, P. A. A., and Bastos, R. O. 2010. "Use of Different Doses of Hidrogel for Sweet Pepper Seedling Production." Pesquisa Aplicada \& Agrotecnologia 3 (2): 53-8. (in Portuguese)

[15] Kumaran, S. S. 2016. "Optimizing the Strength of Hydrophilic Polymers on Yield and Its Contributing Traits in Tomato." International Journal of Applied and Pure Science and Agriculture (IJAPSA) 2 (4): 61-6.

[16] Kumaran, S. S., Ng, H. M., Ramesh, S., Ramesh, K., Vengadaesvaran, B., and Numan, A. 2018. "The Conductivity and Dielectric Studies of Solid Polymer Electrolytes Based on Poly (Acrylamide-co-acrylic Acid) Doped with Sodium Iodide." Ionics 24: 1947-53.

[17] Santos, H. T., Carvalho, D. F., Souza, C. F., and Medici, L. O. 2015. "Lettuce Cultivation on Hydrogel Soils Using Automated Irrigation." Revista Engenharia Agrícola 35 (10): 852-62. (in Portuguese)

[18] Ferreira, V. M., Klar, A. E., Andrade Júnior, A. S., Bastos, E. A., and Oliveira, S. R. M. 2015. "Evapotranspiration and Crop Coefficient of Watermelon Culture in the Teresina Microregion, PI, Brazil." Comunicata Scientiae 6 (4): 488-94. (in Portuguese)

[19] Loose, L. H., Maldaner, I. C., Heldwein, A. B., Lucas, D. D. P., and Righi, E. Z. 2014. "Maximum Evapotranspiration and Crop Coefficient of Eggplant Grown in Plastic Greenhouse." Revista Brasileira de Engenharia Agrícola e Ambiental 18 (3): 250-7. (in Portuguese)

[20] Azambuja, L. O., Benett, C. G. C., Benett, K. S. S., and Costa, E. 2015. "Productivity of Caserta Zucchini as a Function of Nitrogen and Hydroretentor." Científica 43 (4): 353-8. (in Portuguese)

[21] Navroski, M. C., Araújo, M. M., Cunha, F. S., Berghetti, A. L. P., and Pereira, M. O. 2016. "Reduction of Fertilization and Improvement of Substrate Characteristics with the Use of Hydrogel in the Production of Seedlings of Eucalyptus dunii Maiden." Ciência Florestal 26 (4): 1155. (in Portuguese) 